\title{
^UCLPRESS
}

Article title: Ticking Time Bomb: Implications of the Covid-19 Lockdown on E-Waste Management in Developing Countries Authors: Oludamilola Adejumo[1], Olubisi Friday Oluduro[2]

Affiliations: Department of Business Law, Obafemi Awolowo University[1], Department of Public Law, Obafemi Awolowo University[2]

Orcid ids: $0000-0002-0340-804 \times[1]$

Contact e-mail: oaadejumo@oauife.edu.ng

License information: This is an open access article distributed under the terms of the Creative Commons Attribution License (CC BY) 4.0 https://creativecommons.org/licenses/by/4.0/, which permits unrestricted use, distribution and reproduction in any medium, provided the original author and source are credited.

Preprint statement: This article is a preprint and has not been peer-reviewed, under consideration and submitted to UCL Open: Environment Preprint for open peer review.

DOI: $10.14324 / 111.444 / 000065 . v 2$

Preprint first posted online: 11 May 2021

Keywords: coronavirus, COVID-19 lockdown, e-waste, waste management, developing countries, pollution, Environmental protection, Environmental policy and practice, Pollution and health 
Professor Dan Osborn

Editor-in-Chief UCL Open

UCL Open: Environment

Dear Professor Osborn,

We are delighted to submit a revision of our manuscript titled "Ticking Time Bomb: Implications of the Covid-19 Lockdown on E-Waste Management in Developing Countries" for publication in the journal UCL Open: Environment.

We have revised the manuscript in line with the comments raised by both reviewers. Changes made are highlighted in yellow. Summary of the revisions made are as follows:

Reviewer 1

- Discussions in the manuscript has been broadened to include legal framework and implementation challenges in other countries other than Nigeria.

- Summary table highlighting the existing legal frameworks and challenges have been included as suggested.

- Appropriate recommendations to address the identified challenges have been proposed.

Reviewer 2

- Discussions in the manuscript has been broadened to include legal framework and implementation challenges in other countries.

- General discussions on COVID-19 have been broadened to relate the discussions to the environment.

- There are no studies reporting direct evidence of increased importation of ICT devices and electronic waste during the pandemic. However, studies which suggest increased use of ICT devices and options and increased consumption of electrical energy arising from increased use of electronics and ICT devices during the pandemic have been included.

- Brief discussion of impact of the COVID-19 pandemic on the management of waste was included.

- Other suggestions regarding typographical errors and rephrasing statements have been addressed.

We thank you for your kind consideration.

Yours Sincerely,

Oluwadamilola Adejumo

ORCID: 0000-0002-0340-804X 


\title{
TICKING TIME BOMB: IMPLICATIONS OF THE COVID-19 LOCKDOWN ON E-
}

\section{WASTE MANAGEMENT IN DEVELOPING COUNTRIES}

\author{
Oluwadamilola A. Adejumo* and Olubisi F. Oluduro**
}

\begin{abstract}
The coronavirus pandemic has altered the course of events globally since the outbreak of the corona virus disease (COVID-19) late 2019 further giving credence to the long standing belief that the world is indeed a global village. There have been different responses by countries to the raging pandemic including imposition of lockdowns, quarantine and isolation. The imposition of the lockdown whether full or partial, has not been without major consequences leading to resort to information, communication and technological (ICT) based measures to minimize the effect of the lockdown and as an alternative to physical interactions. The use of ICT devices to bridge the gaps created by the lockdown on schools, business offices and other sectors, has led to increased use of electronic devices. The challenge of electronic waste (ewaste) management in developing countries has been on for a while and the increased use of electronic devices is likely to compound the challenge during, and post COVID-19. Whilst the development of ICT based options as viable alternative to face-to-face interactions may not be a negative development, the paper argues that the existing frameworks are inadequate to manage the resultant increase in e-waste in most developing countries and that there is need more than ever before for developing countries to exercise caution in embracing these ICT based options without putting in place measures to ensure that there is increased capacity to manage and dispose the e-waste created thereby.
\end{abstract}

Keywords: coronavirus, COVID-19 lockdown, developing countries, e-waste, e-waste management, non-physical interactions.

\section{Data availability Statement}

Data sharing is not applicable to this article as no new data were created or analysed in this study.

Conflict of Interest: The authors declare no conflicts of interest with this work.

Funding: No funding was received for conduct of this research.

\footnotetext{
*Lecturer, Faculty of Law, Obafemi Awolowo University, Ile-Ife, Nigeria and doctoral Candidate, Faculty of Law, University of Benin, Nigeria.

** Senior Lecturer, Faculty of Law, Obafemi Awolowo University, Ile-Ife, Nigeria.
} 


\section{INTRODUCTION}

The corona virus pandemic has altered the course of events globally since the outbreak of the corona virus disease (COVID-19) late 2019 in Wuhan China. The event has further given credence to the long standing believe that the world is indeed a global village. The virus has spread across countries leading to the declaration of the COVID-19 as a global pandemic by the World Health Organization (WHO) in March 2020. ${ }^{[1]}$ As of $20^{\text {th }}$ January, 2021, a total of 94, 963, 847 cases have been recorded and about 2, 050, 857 deaths recorded across the world.

[2] There have been different responses by countries to the raging pandemic including imposition of lockdowns, quarantine and isolation. Rwanda was the first African country to impose a national lockdown followed by other African countries imposing either total or partial lockdown. ${ }^{[3]}$ The imposition of the lockdown whether full or partial, has not been without major consequences impacting on almost every sector of the economy including the educational, aviation, health and environmental sectors. The resort to information, communication and technological (ICT) measures to minimize the effect of the lockdown and as an alternative to face-face activities has increased significantly. The use of ICT devices to bridge the gaps created by the lockdown on schools, business offices and other crucial sectors, has led to increased use of electronic devices which were initially considered optional or luxurious. The increased use of these devices is not without consequences on the environment. Some of the likely challenges is the increased importation of electronic waste (e-waste) in the name of used electronic devices and the challenge of disposal and management of these devices once they reach end of life stage and become waste. The challenge of e-waste management in developing countries has been on for a while and yet to reach a decisive stage in terms of the resolution of the challenge and thus, the increased use of devices is likely to compound the challenge. 
The aim of this paper therefore is to discuss the environmental impact of the COVID-19 pandemic on developing countries highlighting the challenges inherent in the likely increase in use of electronic and ICT options during the pandemic.

The first part of the paper provides some background information on the COVID-19. The second part discusses the implication of the pandemic and the impact of the lockdown on usual activities whilst emphasising the increased reliance on ICT devices as against usual physical interactions. The paper argues that the lockdown has both positive and negative options which if not adequately controlled and planned for, will create increased e-waste which most developing countries in Africa lack the capacity to manage effectively. The third part provides an overview of electronic waste (e-waste) and discusses e-waste as a challenge most developing countries are faced with. The fourth part of the paper highlights existing legal and institutional framework to manage e-waste highlighting the challenges inherent in the frameworks. The fifth part discusses the way forward for developing countries and the sixth part concludes that the development of ICT options as viable alternative to face-to-face interactions may not be a negative development, however, the existing frameworks are inadequate to manage the resultant increase in e-waste and there is need for measures to minimize the generation of such wastes and its proper disposal during and post COVID-19 lockdown.

\section{THE COVID-19 PANDEMIC}

The COVID-19 is a novelle global pandemic caused by Severe Acute Respiratory Syndrome coronavirus (SARS-CoV-2), of the large family of viruses causing severe diseases, such as the Middle East Respiratory Syndrome (MERS), and Severe Acute Respiratory Syndrome (SARS) ${ }^{[4]}$ It broke out in Wuhan, China around November 2019, spreading quickly across other parts of the globe in less than six months. ${ }^{[5]}$ The WHO on $30^{\text {th }}$ January, 2020 declared that the outbreak constitutes a Public Health Emergency of International Concern (PHEIC). ${ }^{[6]}$ It is now affecting about sixteen million people, with more than half a million fatalities 
globally. It is transmitted primarily from person to person, through droplets from coughing or sneezing or speaking by an infected person to others around him who inhale these droplets community transmission. It could be airborne, as well as through touching of contaminated surfaces like doorknobs, even currencies in circulation and touching their face - eyes, nose or mouth with the hands. ${ }^{[4]}$ Its incubation period is between two and fourteen days, with symptoms including dry cough, fever, fatigue, loss of smell and taste, as well as shortness of breath, sore throat, skin rashes or discolouration of fingers or toes, nasal congestion, leading difficulty in breathing. It may however, be spread before or without manifestation of symptoms - asymptomatic carriers. It may start off as mild to moderate illness, progressing to serious cases including blood clots and multi-organ failures. Some may not require hospitalisation, but for people with underlying medical cases such as diabetes, high blood pressure, cancer, heart and lung problems, etc., particularly adults usually in the upper age bracket, 50 years and above, may be at higher risk as it may result in death or serious health implications after treatment. ${ }^{[4]}$

Research is ongoing on the exact cause of the virus, but it is believed that bats are the mutation agents for the virus, ${ }^{[7]}$ which undergoes certain mutations from which it is transmitted to human beings. Infection figures vary from country to country around the world, with the United States of America leading the fray, daily infection figures are still on the rise. The US alone accounts for almost a quarter of the global figures, ${ }^{[8]}$ while on the African continent, which has the lowest infection rates among other regions of the world, South Africa has the highest infection rates. ${ }^{[8]}$ Africa's low infection rates remain baffling to the rest of the world. Preventive measures such as social distancing, frequent hand washing with water and soap, or rubbing hands with alcohol-based hand sanitisers, use of face masks in public settings are some of the measures to curtail the spread of the virus.

Although, the impact of the outbreak of the virus has been largely negative particularly in the context of public health and safety, some positive implications of the outbreak on the 
environment have been recorded. The reduction in industrial activities, tourism, travel and flights across the globe have actually had a positive impact on the environment resulting in reduction of release of pollutants. Indeed, some countries reported drop in carbon emissions. ${ }^{[9]}$ These developments may however be considered temporary as there is likelihood that these temporary gains may be lost once the tide of the raging pandemic stems low and most activities return to status quo. Despite these temporary gains, there is need to focus on likely dangers that the pandemic portends to the environment now and in the near future.

\section{IMPLICATIONS OF COVID-19 LOCKDOWN AND INCREASED RELIANCE ON ICT ALTERNATIVES TO PHYSICAL INTERACTIONS}

As part of measures to ensure social distancing and reduce the spread of COVID-19, lockdown was imposed in countries across the world. Mitra et al in their study reported that transmission of COVID-19 is via airborne droplets and to effectively control its spread, there is need to reduce concentration of persons in public meeting places. ${ }^{[10]}$ Indeed, this appears to be the rationale for the imposition of either total or partial lockdowns by most countries in response to the outbreak of COVID-19.

The lockdown led to closure of schools, hospitals, offices and business, reduced local business travel among others. Only a few essential services were operating. The closure of schools for instance meant that pupils were home and measures were put in place to ensure they were engaged while at home. Toquero reported that higher educational institutions were closed in about 188 countries across the world as of $6^{\text {th }}$ April, 2020 owing to vulnerability of school settings to the spread of the COVID-19. ${ }^{[11]}$ The closure led to the introduction of online system of learning which most schools were not prepared for although some countries like Hong Kong and China reverted to online mode of teaching when schools had to be closed during the outbreak of the Severe Acute Respiratory Syndrome in 2003. Mitra et al also corroborated the fact that teaching and assessment of students have moved online, on an untested and 
unprecedented scale. ${ }^{[10]}$ This pattern is likely to continue even after the pandemic as there is a strong likelihood that the e-learning will continue to complement traditional learning patterns. Apart from the closure of schools, the imposition of local or national lockdowns also resulted in the closure of health services which were deemed non-essential. ${ }^{[12]}$ The increasing number of COVID-19 cases has caused a huge strain on the health care systems in most countries with facilities and personnel required for management and treatment of patients getting strained. Also, the fact that health care workers are exposed to high risk of infection by COVID 19 patients in the course of treatment of these patients ${ }^{[13]}$ made the desire to visit hospitals to seek care for other ailments non-desirable.

The rate of infection of health care workers (HCWs) across the globe is becoming increasingly worrisome. In Africa alone, the WHO in May 2020 reported infection of 945 health workers in 28 countries in the Africa with South Africa having the highest number of infected health workers. ${ }^{[14]}$ Updated report released by 26th May, 2020 revealed that Nigeria has a record of the highest number in the region with 606 health workers having been infected with the coronavirus. ${ }^{[15]}$ This has made the resort to non-physical visits to hospital for consultation and treatment a preferred option via tele-medicine channels. Vidal-Alaball et al ${ }^{[16]}$ posit that telemedicine is capable of providing support to the healthcare systems in the midst of this pandemic whilst advocating for its continued use even after the pandemic ends. They reported that countries like China, South Korea, Spain, United States of America, Japan and many European countries are at different stages of experimenting and implementing telemedicine. O'Leary also reported the development of various applications (apps) to slow the spread of COVID-19. The apps are used to track the coronavirus or to check symptoms. All these apps require a smart phone to use them as the app uses information from the user's phone to determine if they have been in contact with any person with the virus. ${ }^{[17]}$ 
In the same vein, religious activities have also moved largely online with services and prayer meetings being conducted on different online platforms across the world. Places of worship recognized the spiritual needs of the faithful, and created access to their programmes through social media platforms holding livestream worship on Facebook, Twitter, YouTube, websites and other platforms. ${ }^{[18]}$ E-commerce, contact free buying and selling and business meetings have also thrived in a bid to ensure social distancing. The 2020 Annual General Meeting (AGM) of the Nigerian Bar Association for instance was a strictly online event, and was the first ever virtual AGM to be held by the Association. ${ }^{[19]}$ All these virtual events and activities will require use of one form of electronic device or the other.

Goldschmidt reported growing reliance on the use of technology to learn, live, and stay connected. The study placed emphasis on use of technology to leverage and maintain social, physical, emotional and even spiritual wellbeing for children as closure of parks, playgrounds and other social services centres were not uncommon during the pandemic ${ }^{[18]}$ with children having to rely largely on use of devices for play and entertainment.

Jiang et al reported extra energy demands in their study arising from energy consumed by confinement measures including from working from home and telemedicine during the pandemic. ${ }^{[20]}$ They specifically attributed the increased energy demand to increased use of ICT devices to support digitalization and tele-work during the lock-down in both developed and developing countries.

Although the lockdown has come with some gains for the environment with reports of significant reduction in emissions and pollution ${ }^{[10,21]}$, the lockdown also comes with looming challenges for the environment if adequate plans are not put in place to address them. O'Leary particularly notes that there is a strong likelihood that business, organizations, culture, and society will be forever changed by all the adaptations to the pandemic as solutions 
generated by the information systems and technology communities will be used even in future settings and post-COVID-19 pandemic. $^{[17]}$

\section{THE E-WASTE CHALLENGE IN DEVELOPING COUNTRIES}

E-wastes consist of damaged or outdated electronic devices, products, materials and spare parts. They are electronic devices which are discarded or dumped by the owners or buyers after the end of its useful life, or because of rapid expansion of technology, or consumption change in society. These may not necessarily be out rightly damaged, but may be refurbished, reused (working and repairable electronics), resold, refined, or salvaged through recycling.

The world is currently generating e-waste faster than it can be recycled or repurposed. Electronic waste will increase to 52 million metric tonnes by 2021, and 120 million tonnes yearly by 2050 , of which only $20 \%$ would be recycled. ${ }^{[2,23]}$ As a result of this, e-wastes are generally imported, mostly illegally to developing countries of Africa from the developed countries of Europe, America and Asia, notwithstanding the ban on same through various international Conventions. ${ }^{[24-28]}$ They are peculiar in that they are known to contain hazardous substances like toxic metals and organic chemicals, sake of which they require due care in handling, failing which they can cause an array of diseases in humans handling them inappropriately. Such diseases include genomic, respiratory, neurodevelopment, reproductive, and hormonal systems. ${ }^{[29]}$ Waste management has been the bane of many countries, more so electronic waste otherwise called end-of-life-electronics equipment (EEE).

Throughout much of human history, waste has always had an inherent value, ${ }^{[30]}$ yet waste management is one of the greatest environmental challenges, as enormous wastes are generated daily resulting in gargantuan annual volumes globally, running to more than 50 million metric tonnes of defunct electronic products. The higher percentage of these are classified as hazardous because they contain toxic chemicals. 
Used electronic equipment are dumped on the developing countries daily by the developed countries in very high degree. ${ }^{[31]}$ The unfortunate aspect of this is that, the former lacks the requisite technologies and techniques for processing e-waste, hence primitive recycling technologies are employed by these which expose them to significant health risks through contacts with a range of hazardous substances contained in them such as lead, brominated flame retardants, chromium, lithium, mercury, cadmium, polychlorinated biphenyls (PCBs).

Nigeria's fast-growing second-hand computer industry enhances large scale computer waste importation, with the nation's ports handling estimated 500 container loads each carrying about 500,000 used computer and other electronic equipment month, form the USA, Europe and Asia. Lagos, the commercial capital harbours two large second-hand electronics markets - Alaba International Market and the Computer Village, with up to 500 tons coming in daily, mostly shipped as used electronics. ${ }^{[32]}$ It is not uncommon in Nigerian markets to find people marketing United Kingdom (UK) used products as a preferred option to brand new electronic products which are believed to be of less durable quality. Slangs such as UK used are commonly used in marketing fairly used mobile phones and laptops.

The cost of recycling e-waste in developed countries also encourages shipment of used electronic equipment to developing countries which have a thriving market for these equipment and which have to deal with the responsibility to dispose them once they eventually pack up. Most of these devices end up being disposed improperly or by resort to primitive recycling methods. Fehm notes that e-waste recycling is not only quite expensive but also labour intensive as the parts are ordinarily not intended to be taken apart. ${ }^{[33]}$ The process of recycling e-waste requires expensive machinery and sophisticated procedures which most developing countries cannot boast of. The resort to primitive recycling methods by developing countries may cause serious human health hazards particularly in children who are more vulnerable where their functional systems like the central nervous immune, reproductive and digestive 
systems which are still developing may be hampered by exposure to toxic substances, such damage which might be irreversible.

Recycling is a form of disposal of e-waste in Nigeria, springing up in Lagos and a couple of other cities. Though largely done informally, it is focused on selected valuable materials. Participants are either itinerant waste buyers or scavengers who target valuable materials such as plastics, CPUs, batteries, screens, glass and metals alike. Their activities can have an impact on the reduction of the net volume of disposed e-wastes. Waste burning is also common in Nigeria. Burning of waste has a well-documented association with the incidence of respiratory health symptoms among adults and children. Burning of toxic wastes produce chemicals such as dioxins, furans and dioxin-like poly chlorinated biphenyls which are suspected carcinogens that damage the nervous and immune systems, and are quite harmful even in miniscule quantities. ${ }^{[34,35]}$

Landfills are a standard method for disposing of wastes in the developed and developing worlds. However, improperly built landfills can cause environmental and human health problems. Just as densely packed organic matters produce methane as it rots, toxic wastes can cause even more devastation as it can cause explosions. Bacteria working on these matters can break down waste acids and particulars which can be concentrated enough to dissolve poisonous heavy metals such as lead and cadmium among others. Water leaching through the landfill can carry such toxins into the groundwater or nearby bodies of water and from there, into drinking water and thus into the food chain. ${ }^{[36]}$ The Olusosun landfill in Lagos is Africa's largest and the world's fourth largest, covering an estimated 43 hectares and 18 meters deep, being in existence for several decades with no plan to transform or close it. Aside from being a beehive of activities to hordes of scavengers daily sourcing for disposed waste items, it has been a place of accommodation to many (scavengers), who work at the site and live in tents atop the trash, creating a village on top of the trash. Besides, it is hedged in-between residential 
part of the bustling city, about 5 million live around 10 kilometres radius from the site. ${ }^{[32,37]}$ The site is ever burning, releasing toxic fumes into the air with blanket of soot over the area, affecting the scavengers and residents in the area. Diseases such as skin irritation, dysentery, water related diseases, paralysis, nausea are reported by residents living around 3 kilometres radius from the site. ${ }^{[38]}$

The larger percentage of African countries are poor with the greater percentage of the people living off the environment, directly or otherwise attached to the land and the resources from it. ${ }^{[39]}$ Coupled with this is the state of awareness of the people, as thousands of the scavengers are basically unaware of how dangerous their work is, which accounts for why human beings would with bare hands dismantle items which contain mercury, lead, beryllium, lithium among others, constituting great risk to their health. These could lead to adverse like inflammation and oxidative stress that could aggravate to cardiovascular diseases, chronic kidney diseases, cancer and DNA damage. ${ }^{[40]}$

Arising from the pandemic, there have been reports of challenges of waste management particularly, management of bio-medical wastes in developing countries. ${ }^{[41]}$ Changes in waste disposal patterns have also posed a huge challenge to waste management during the pandemic especially in developing countries. Oyedotun et al specifically highlighted the possibility of cross-contamination between residents and landfill scavengers who dismantle wastes during the pandemic. ${ }^{[42]}$

\section{LEGAL AND INSTITUTIONAL FRAMEWORK FOR MANAGEMENT OF E- WASTE AND THEIR CHALLENGES}

\section{A. International and Regional frameworks}

The first international attempt to address the exportation of e-waste from developed to developing countries was made under the Basel Convention on the Control of Transboundary Movements of Hazardous Wastes and their Disposal which was adopted in 1989. ${ }^{[24]}$ The 
Convention specifically addresses the vulnerability of least developed countries (LDCs) due to the increasing likelihood of businesses from industrialized states disposing of their hazardous waste in cheaper as well as less environmentally regulated countries and promotes observance of environmentally sound waste management principles. ${ }^{[24]}$ The United States which is one of the largest exporter of hazardous waste, has only signed but has not ratified the Basel Convention and continues to export hazardous waste, and in particular e-waste, to least developed countries. McAllister et al notes in this context that people most severely affected by e-waste are effectively unrecognized by those who are most responsible for generating the waste. $^{[43]}$

The Bamako Convention came as a follow up to the Basel Convention in 1991. ${ }^{[25]}$ The Convention is a regional response by African countries to address the issue of importation of hazardous waste to African Countries from developed countries. ${ }^{[44]}$ Initially negotiated by 12 countries, the Bamako Convention currently has been ratified by 25 countries and the Convention is considered to be stronger than the Basel Convention in its prohibition of importation of hazardous waste as it allows no exceptions. ${ }^{[25,44]}$ Obligations under the Bamako Convention includes an obligation to ensure minimum reduction of generation of hazardous waste and prevention and minimizing effect of pollution in management of hazardous wastes. ${ }^{[25]}$

Illegal dumping of e-waste by whatever means on the developing nations which have not the requisite technology to recycle same also constitutes a negation of Article 191 Treaty on the Functioning of the European Union (TFEU), which provides for the protection of human health, one of the objectives of the Community policy on the environment. The policy which aims at a high level of protection is based on precautionary principle, the requirements of which must be integrated into the definition and implementation of other Community policies. It further flows from the case law of the European Court that the precautionary principle may 
also apply in policy on the protection of human health, which according to Article 168 TFEU, likewise aims at a high level of protection. ${ }^{[45]}$ In the Wallonian Case, ${ }^{[46]}$ the Court considered a Wallonian ban on the import of waste from anywhere outside the region of Belgium on the basis of proximity principle, namely that waste should be disposed of as close to the place of production as possible. This is to avoid environmental costs and risks of transporting the waste, and it establishes a principle of environmental equity. Clean places are not to bear the environmental costs generated by dirty places. Contrastingly, the Court in Dusseldorp Case, ${ }^{[47]}$ an application to export two loads of oil filters for processing was refused by the Dutch authorities on the grounds that, under Dutch law, export of waste for recovery was only permitted if there were superior processing techniques abroad, or there was insufficient capacity in the Netherlands. The Court of Justice noted that such an export restriction provided an advantage for national facilities. The whole idea behind dumping of e-waste on developing countries where these goods may be subsequently processed in dangerous and inefficient conditions as obtained more particularly in the West African sub-region, harming the health of local people and damaging the environment negates substantially the provisions of the Basel Convention and the OECD rules on hazardous and toxic wastes, to which some of these developed countries are parties. ${ }^{[31]}$

Various international calls for action in recent times include the Libreville Declaration being the first Inter-Ministerial Conference on Health and he Environment in Africa in 2008, the Busan Pledge for Action on Children's Environmental Health 2009, and the Strategic Approach to Integrated Chemical Management's expanded Global Plan of Action ICCMM3 2012. ${ }^{[26]}$ The world's first forum on e-waste was convened in 2006 at the $8^{\text {th }}$ meeting of the CoP to the Basel Convention, leading to the Nairobi Declaration on creating innovative solutions for the environmentally sound management of electronic wastes, but this does not seem to have any form of bearing or influence on many of the developing countries take on the subject-matter as 
illegal trading in it grows unabated, to the detriment of their environment and the people's health.

\section{B. National frameworks and challenges of e-waste management in some developing Countries}

Apart from the efforts noted above at international and regional levels, countries have also made efforts to combat the e-waste challenge. In developed countries, there are advanced approaches to e-waste management which helps to regulate to a large extent e-waste management. Approaches such as the European Union Extended Producer Responsibility (EPR), the Consumer Pays Model and charging of Advanced Recycling Fees at point of purchase have been somewhat effective. Some developed countries have also made significant efforts to adopt upstream recycling methods and have the infrastructure and expertise for upstream recycling of e-waste. However, this is not the case in developing countries. Gamaralalage and Premakumara notes that the progress in the practical implementation of national regulations on e-waste at the local level is limited and challenging. ${ }^{[48]}$ Existing frameworks in some developing countries are discussed below.

The state of Nigeria's legal and policy disposition to hazardous waste is parlous and unexpected to say the least, considering that the nation was jolted to consciousness of the environment by the dumping of hazardous waste on Koko by Gianfraco Raffaeli, an Italian businessman in 1988. ${ }^{[49]}$ This incident brought about Nigeria taking major steps at fixing its environmental issues with the promulgation of the Harmful Toxic Waste (Special Criminal Provision) Act, ${ }^{[50]}$ establishment of the defunct Federal Environmental Protection Agency (FEPA), and a National Policy on the Environment to bring the nation to life on current environmental trends. Much as that would be, the situation is almost the same today for many obvious reasons major among which is poverty. ${ }^{[27]}$ The country for instance cannot thus be said to be fully ready to effectively handle an increase in generation of e-waste which is likely to arise during and after 
the COVID-19 pandemic. The need to bridge the 'digital divide' to meet technological needs and demands of technological advancements will continue to encourage illegal importation of waste electrical/electronic equipment (WEEE) in the name of 'used' electrical products.

The Harmful Waste Act promulgated after the Koko incident was specifically directed at addressing importation of toxic waste. The Act prohibits the importation, carrying, deposition and dumping of harmful waste on any land, territorial waters and matters relating thereto. Although the penalty for commission of the above offence under the Act is life imprisonment, not much success has so far been made despite the Act. The very porous borders in the country has made the effect of the provision largely redundant as WEEE is still finding its way into the country. In the same vein, the Act also requires persons who generates hazardous waste to cause such waste to be treated using acceptable methods. This provision has also remained largely unenforced as most users of electronic equipment at end of life stage dispose same in the same way other wastes are disposed of. Burning of e-waste without regard to the danger to the environment in a bid to extract copper and gold is also not unusual.

The establishment of the National Environmental Standards Regulation and Enforcement Agency (NESREA) in 2007 as a replacement for FEPA brought about some progress in the framework for addressing the e-waste management challenges in Nigeria. The Agency has made a total of 33 Regulations for protection of the environment since inception, only two of these Regulations relate to e-waste. The National Environmental (Sanitation and Wastes Control) Regulations 2009 ${ }^{[51]}$ and the National Environmental (Electrical/Electronic Sector) Regulations 2011. ${ }^{[52]}$ In addition, the Agency has also released a Guide for Importers of Used Electrical and Electronic Equipment into Nigeria. The Guide reiterates the ban on importation of WEEE and requires all importers to register with the Agency.

The National Environmental (Sanitation and Wastes Control) Regulations 2009 prohibits littering with wastes, encourages segregation of waste and disposal in designated areas. 
Although the Regulation recognizes different categories of wastes including health care waste, solid wastes and effluent discharge, it fails to expressly recognise e-waste as a distinct category worthy of specific provisions, this was however subsequently covered under the 2011 National Environmental (Electrical/Electronic Sector) Regulations discussed below. Nevertheless, provisions relating to toxic and hazardous wastes under the Regulation will apply to e-wastes. There is an obligation to ensure that every container or package for storing hazardous waste is secured, marked and labelled. Despite the provision of the Regulations, waste segregation and labelling is still not commonly practiced in the country.

The National Environmental (Electrical/Electronic Sector) Regulations 2011 makes a more detailed attempt to regulate e-waste importation, disposal and management. The Regulation anchored on the 5Rs of reuse, reduce, recycle, repair and recover seeks to minimize pollution from electronics and electrical equipment from 'cradle to grave'. The Regulation relates to both new and used electrical and electronic equipment and advocates the principle of extended producer responsibility including a buy-back plan for management and disposal of e-waste. It imposes responsibility not only on product manufacturers but on distributors, retailers and importers to take back end of life products from consumers at designated collection centres where manufacturers and producers are to ensure disposal in an environmentally sound manner. The Regulation prohibits importation of end of life, unusable, unserviceable electronics and cathode ray tubes. It prohibits burning of e-wastes; disposal in land-fills and dump sites; and storage on-site for more than one year and imposes penalties for breach. It requires recycling of e-wastes at designated recycling centres. In addition, the Nigerian Communications Commission (NCC) in 2019 adopted the E-waste Regulations for players in the Communications Industry. This is intended to complement NESREA's Regulations and regulate the life-cycle of electronic and electrical equipment and both Agencies are expected 
to work together toward building effective partnership for the enforcement of environmental laws and regulations. ${ }^{[53]}$

Although the National Environmental (Electrical/Electronic Sector) Regulations is quite detailed in its provisions relating to e-waste importation, management and disposal, not much progress has been achieved in terms of its effective implementation and enforcement. A recent report revealed shipment of more than 60,000 tonnes of used electrical and electronics equipment into Nigeria annually via Lagos Port alone. This is in addition to shipment from land borders and other ports. Of this number, more than $25 \%$ of the shipped equipment can be categorised as being 'dead on arrival' and of no use. ${ }^{[54]}$

Concerns were still raised as recent as January 2020 over the dangers of e-waste management challenges and crude recycling practices with government being urged to create an enabling environment for recycling plants to spring up and function effectively. ${ }^{[55]}$ Other challenges identified by NESREA in combating the e-waste challenge include poor implementation of the extended producer responsibility programme and poor public awareness on the dangers of ewaste. ${ }^{[56]}$

In Ghana, there was no detailed legislation on management of e-waste in until after 2014. ${ }^{\text {[57] }}$ There was however, the Prohibition on Manufacture, Sale and Import of Incandescent Lamps and Sale and Import of Used Refrigerators, Freezers and Air Conditioners, Regulations, LI 1932 (2008). Although Ghana is also a Party to the Basel Convention, same is yet to be domesticated under their national laws. ${ }^{[58]}$ The enactment of the Hazardous and Electronic Waste Control and Management, Law, Act 917 of 2016 in Ghana was the beginning of a specific legal regime for management of e-waste in Ghana. The Act requires manufacturers and importers of electronic equipment to register with the Environmental Protection Agency and to pay an e-waste levy expected to cover cost of effective management of e-waste. ${ }^{\text {[59] }}$ 
There is also the Hazardous, Electronic and Other Wastes (Classification) Control and Management Regulations (2016) (L.I. 2250).

Nevertheless, the laws appear more focused on the formal sector and neglects the informal sector. The informal sector is thriving as young men without jobs resort to house to house buying of e-waste and delivery to dumpsites at a fee. Informality of e-waste recycling which is common in most developing countries is closely linked to poverty and poor economic status of citizens. ${ }^{[58]}$ This informal practices are largely unregulated and difficult to regulate particularly as most of the stakeholders find it quite financial rewarding.

Oteng-Ababio and Amankwa ${ }^{[57]}$ reports that attempt to introduce EPR by two companies in Ghana failed woefully as the responses to calls for return of obsolete products by consumers yielded very low response rate. This is perhaps because the incentives were not compelling enough. Thus, about $95 \%$ of e-waste recycling is being done informally in an unregulated manner and with reports of extortion of the key stakeholders by the authorities who perceive them as persons involved in some form of illegal activities.

In Kenya, the National Environmental Management Authority (NEMA) formulated guidelines for e-waste management in 2010 as part of efforts to manage e-waste effectively by all stakeholders. Similar to the efforts of the NCC in Nigeria to complement the Environmental Agency's efforts, an ICT policy was also formulated by the Ministry of ICT to ensure that players in the ICT sector have plans to reduce the impact of their ICT infrastructure on the environment before renewal of their licenses by the Ministry. ${ }^{[59]}$ Otieno and Omwenga identified challenges of e-waste management in Kenya to include poor public awareness of negative impact of e-waste, absence of needed capacity to implement and enforce policies on the part of regulatory agencies, poor waste collection practices that does not allow for segregation of e-wastes and thriving informal e-waste handling owing to the prevalence of poverty. ${ }^{[59]}$ 
Similar to what obtains in developing African countries, China and India did not have any specific legislation to regulate importation of e-waste until 2000. The E-Waste Management and Handling Policy was also not introduced in India till 2011 and the EPR Policy in China in 2012. ${ }^{[60]}$ Prior to the 2012 Policy however, China had introduced the Circular Economy Promotion Law Administrative Rules on Prevention of pollution by WEEE and Collection and Treatment Decree on Waste Electrical and Electronic Equipment in 2008 and 2011 respectively to prevent e-waste related pollution and regulate recycling activities. ${ }^{[60]}$ In 2018 , India also introduced the E- Waste (Management) Amendment Rules (2018). [61]

Patil and Ramakrishna recognised the challenges in India to include illegal importation, crude processing arising from lack of finance and infrastructure for formal recycling, defective legislations with no penalty for non-compliance to have deterrent effect and poor public awareness on proper handling and disposal of e-waste. ${ }^{[60]}$ Challenges in China similar to Ghana include the lack of regulation for the informal sector which carries out most of the recycling activities in both countries. Lack of infrastructure for formal recycling, fragmentation of existing laws and weak enforcement efforts were also identified as challenges of e-waste management in China. ${ }^{[60]}$

The situation in Nigeria is not quite different from what obtains in other developing countries. The fact that most developing countries that have passed laws and made e-waste regulations only have such laws and regulations in principle without clearly spelt out outlines on the practicalities and financial mechanisms for implementing the laws was emphasised by Supian et al. ${ }^{[62]}$ They identified poor public awareness on proper handling of e-waste, overall management issues including policy making and implementation; and poor financing as ewaste management challenges faced by most developing countries.

Few developing countries that have succeeded in establishing formal recycling including Japan and South-Korea also have some critical challenges. Chung and Murakami-Suzuki reported 
increased illegal export of e-waste to neighbouring countries to circumvent financial liabilities associated with recycling obligations. ${ }^{[63]}$

Table 1- Summary of e-waste management framework in some developing countries and identified challenges

\begin{tabular}{|c|c|c|}
\hline Country & Framework for e-waste Management & Challenges \\
\hline Nigeria & $\begin{array}{l}\text { a) Harmful Toxic Waste (Special } \\
\text { Criminal Provision) Act } 1988 \\
\text { b) National Environmental (Sanitation } \\
\text { and Wastes Control) Regulations } \\
2009 \\
\text { c) National Environmental } \\
\text { (Electrical/Electronic Sector) } \\
\text { Regulations 2011. } \\
\text { d) } \text { Guide for Importers of Used } \\
\text { Electrical and Electronic Equipment } \\
\text { into Nigeria } \\
\text { e) Nigerian Communications } \\
\text { Commission (NCC) E-waste } \\
\text { Regulations for players in the } \\
\text { Communications Industry } 2019\end{array}$ & $\begin{array}{l}\text { a) Weak enforcement } \\
\text { mechanisms } \\
\text { b) Poor implementation } \\
\text { of the extended } \\
\text { producer } \\
\text { responsibility } \\
\text { programme } \\
\text { c) Poor public } \\
\text { awareness and } \\
\text { sensitization. borders } \\
\text { d) Porous for } \\
\text { allowing } \\
\text { smuggling of e-waste } \\
\text { e) Thriving informal } \\
\text { recycling sector } \\
\text { owing to poverty and } \\
\text { poor economic } \\
\text { conditions } \\
\text { f) Unattractive } \\
\text { environment for } \\
\text { investment in formal } \\
\text { recycling projects }\end{array}$ \\
\hline Ghana & $\begin{array}{l}\text { a) Prohibition on Manufacture, Sale and } \\
\text { Import of Incandescent Lamps and } \\
\text { Sale and Import of Used } \\
\text { Refrigerators, Freezers and Air } \\
\text { Conditioners, Regulations, LI } 1932 \\
\text { (2008) } \\
\text { b) Hazardous and Electronic Waste } \\
\text { Control and Management, Law, Act } \\
917 \text { of } 2016 \\
\text { c) Hazardous, Electronic and Other } \\
\text { Wastes (Classification) Control and } \\
\text { Management Regulations (2016) (L.I. } \\
\text { 2250). }\end{array}$ & $\begin{array}{l}\text { a) Thriving informal } \\
\text { recycling sector } \\
\text { owing to poverty and } \\
\text { poor economic } \\
\text { conditions } \\
\text { b) Unregulated informal } \\
\text { sector } \\
\text { c) Poor incentives for } \\
\text { compliance with EPR } \\
\text { programme }\end{array}$ \\
\hline Kenya & $\begin{array}{l}\text { a) National Environmental Management } \\
\text { Authority (NEMA) Guidelines for e- } \\
\text { waste management, } 2010\end{array}$ & $\begin{array}{l}\text { a) Poor public } \\
\text { awareness of } \\
\text { negative impact of e- } \\
\text { waste }\end{array}$ \\
\hline
\end{tabular}




\begin{tabular}{|c|c|c|}
\hline & $\begin{array}{l}\text { b) Information Technology (ICT) Policy } \\
\text { by the Ministry of ICT }\end{array}$ & $\begin{array}{l}\text { b) Absence of needed } \\
\text { capacity to } \\
\text { implement and } \\
\text { enforce policies } \\
\text { c) poor waste collection } \\
\text { practices that does } \\
\text { not allow for } \\
\text { segregation of e- } \\
\text { wastes and thriving } \\
\text { informal e-waste } \\
\text { handling owing to the } \\
\text { prevalence of poverty }\end{array}$ \\
\hline India & $\begin{array}{l}\text { a) E-Waste Management and Handling } \\
\text { Policy } 2011 \\
\text { b) E- Waste (Management) Amendment } \\
\text { Rules (2018) }\end{array}$ & $\begin{array}{l}\text { a) Illegal importation } \\
\text { b) Crude processing and } \\
\text { recycling arising from } \\
\text { lack of finance and } \\
\text { infrastructure for } \\
\text { formal recycling } \\
\text { c) Defective legislations } \\
\text { with no penalty for } \\
\text { non-compliance to } \\
\text { have deterrent effect } \\
\text { d) Poor public } \\
\text { awareness on proper } \\
\text { handling and disposal } \\
\text { of e-waste }\end{array}$ \\
\hline China & $\begin{array}{l}\text { a) Circular Economy Promotion Law } \\
\text { Administrative Rules on Prevention } \\
\text { of pollution by WEEE } 2008 \\
\text { b) Collection and Treatment Decree on } \\
\text { Waste Electrical and Electronic } \\
\text { Equipment } 2011 \\
\text { c) EPR Policy } 2012\end{array}$ & $\begin{array}{l}\text { a) Lack of regulation for } \\
\text { the informal sector } \\
\text { b) Lack of infrastructure } \\
\text { for formal recycling } \\
\text { c) Fragmentation of } \\
\text { existing laws } \\
\text { d) Weak enforcement } \\
\text { efforts }\end{array}$ \\
\hline
\end{tabular}

\section{WAY FORWARD}

It appears clear from the foregoing that having a legal framework without clear implementation strategies will not effectively help in combating e-waste management challenges. Imposing restriction on import of used electronics may not be feasible owing to porous borders and poor economy where it is difficult to afford brand new products. The high level of poverty will also continue to foster activities of informal recyclers and e-waste managers. The practice of 
copying the framework and strategies of developed countries without the financial ability to implement and without clearly spelt out guidelines for implementing which takes into cognizance practicality and economic realities are bound to fail.

An ideal e-waste legislation should thus be one that includes a complete ban on e-waste import/export; prohibits crude processing and strengthens and equips informal sectors; enforce EPR principles; and encourage formal recycling industry and rewards consumers for their responsible actions. ${ }^{[64]}$ Nnorom and Osibajo ${ }^{[65]}$ calls for adequate and necessary amendment of existing legislations and implementation process for achieving a higher recycling rate. In carrying out the amendment process, views of stakeholders especially the key players in the informal sectors should be accommodated as much as possible in the planning, implementation and monitoring processes. Thus, Patil and Ramakrishna ${ }^{[60]}$ recommends a legislation that defines responsibility of all stakeholders including government agencies, enforcement officers, producers, consumers and the informal recyclers.

Apart from legislation, Liu et al ${ }^{[66]}$ recommends building of environmental protected industrial parks where the recycling of e-wastes should be performed to alleviate the negative impact of e-wastes on the environment. This can be done via public private partnership. ${ }^{[59]}$

Developing countries should also begin to research on phytoremediation and bioremediation to transform environment contaminated by e-waste. This is even more necessary now that there is increased use of electronic equipment and the resultant waste to be generated over time. ${ }^{[67]}$ There is also an urgent need to promote public awareness of the risks involved in improper handling of e-waste.

Technology development and information exchange on best management practices should be encouraged among developing and developed countries. Stronger commitment should be made by government of developing countries toward enforcement of existing laws and national regulations, particularly the Basel Convention and the Bamako Convention particularly among 
countries in the West African region which is the major hub of trade in used electrical equipment and e-waste importation. ${ }^{[68]}$ Stricter measures at regulating the movement of ewaste substances from the UK, the USA and the EU member states should be put in place with developing states being able to prohibit or object to shipments of waste in order to implement the principles of proximity and self- sufficiency. ${ }^{[69]}$

\section{CONCLUSION}

The desire for technological advancement and alternative ICT based options created to address the effect of the COVID-19 lockdown is changing settings in the developing world. The situation in developing countries, according to Sullivan is 'not pretty' ${ }^{[68]}$ Indeed, it is a ticking time bomb which may explode soon, if not defused timeously. The resort to ICT measures to minimize the effect of the lockdown and as an alternative to face-face activities is increasing and is likely to remain so even post-COVID-19 as some of these innovations are likely to remain complementary to traditional physical interactions. This will invariable lead to increase in importation of electrical and electronic devices and a consequential increase in generation of e-waste.

Based on the foregoing, there is need for Nigeria and other developing countries to take caution in embracing the increased reliance on technological innovations as an alternative to physical interactions as necessitated by the COVID-19 pandemic. Whilst the use of ICT options as a viable alternative to face-to-face interactions may not be a negative development during and post COVID-19 pandemic, the existing frameworks are inadequate to manage the resultant increase in e-waste. There is need for developing countries to not only start the conversations and plan for managing the looming increased e-waste situation but to start putting measures in place to minimize the generation of such wastes and to ensure its proper disposal in an environmentally sound manner during and post COVID-19. The problems associated with informal recycling of e-waste will continue to spread in developing countries in Africa, Asia, 
and the Indian subcontinent with these countries increasingly becoming major receptacles for the developed world's unwanted electronics and electrical equipment. 


\section{References}

1. World Health Organization (WHO), 'WHO Director-General's opening remarks at the media briefing on available at https://www.who.int/dg/speeches/detail/who-director-general-s-opening-remarks-atthe-media-briefing-on-covid-19---11-march-2020 (accessed 15 June 2020).

2. WHO, 'Coronavirus Disease (COVID-19) Dashboard' available at https://covid19.who.int/ (accessed 21 January 2021).

3. WHO, 'African countries start easing COVID-19 confinement measures,' available at https://www.afro.who.int/news/african-countries-start-easing-covid-19-confinementmeasures (accessed 3 July 2020).

4. WHO, 'Q\&A on Coronaviruses (COVID-19),' 17 April, 2020, available at https://www.who.int/emergencies/diseases/novel-coronavirus-2019/question-andanswers-hub/q-a-detail/q-a-coronaviruses/ (accessed 15 June 2020).

5. WHO, 'WHO Situation Report \#87,' 16 April, 2020, available at https://www.who.int/docs/default-source/coronairuse/situatio-reports/20200416sitrep-87-covid-19.pdf?sfvrsn=9523115a_2.pdf_(accessed 15 June 2020).

6. WHO, 'COVID-19 Public Health Emergency of International Concern (PHEIC), Global Research and Innovation Forum', 12 February, 2020, available at https://www.who.int/publications/m/item/covid-19-public-health-emergency-ofinternational-concern-(pheic)-global-research-and-innovation-forum (accessed 15 June 2020).

7. Eschner K. The Virus that Causes COVID-19 Has Been Silently Brewing in Bats for Decades. Popular Science Online, 2020 available at https://www.msn.com/en$\mathrm{xl} /$ northamerica/top-stories/the-virus-that-causes-covid-19-has-been-silently-brewingin-bats-for-decades/ar-BB17ofDa?ocid=mailsignout (accessed 15 July 2020).

8. WHO, 'Weekly epidemiological update' available at https://www.who.int/publications/m/item/weekly-epidemiological-update---19january-2021 (accessed 21 January 2021).

9. Henriques M. Will Covid-19 have a lasting impact on the environment. BBC News, London, March. 2020 Mar;27.

10. Mitra A, Ray Chadhuri T, Mitra A, Pramanick P, Zaman S. Impact of COVID-19 related shutdown on atmospheric carbon dioxide level in the city of Kolkata. Parana Journal of Science and Education. 2020;6(3):84-92.

11. Toquero CM. Challenges and Opportunities for Higher Education Amid the COVID19 Pandemic: The Philippine Context. Pedagogical Research. 2020;5(4).

12. Riley T, Sully E, Ahmed Z, Biddlecom A. Estimates of the potential impact of the COVID-19 pandemic on sexual and reproductive health in low-and middle-income countries. Int Perspect Sex Reprod Health. 2020 Apr 16;46:46.

13. Lai X, Wang M, Qin C, Tan L, Ran L, Chen D, Zhang H, Shang K, Xia C, Wang S, Xu S. Coronavirus disease 2019 (COVID-2019) infection among health care workers and implications for prevention measures in a tertiary hospital in Wuhan, China. JAMA Network Open. 2020 May 1;3(5):e209666

14. WHO, 'COVID-19 WHO African Region: External situation report 10,' available at https://apps.who.int/iris/bitstream/handle/10665/331989/SITREP_COVID19_WHOAFRO_20200506-eng.pdf (accessed 9 June 2020).

15. WHO, 'COVID-19 WHO African Region: External situation report 13,' available at https://apps.who.int/iris/handle/10665/332199 (accessed 8 June 2020). 
16. Vidal-Alaball J, Acosta-Roja R, Hernández NP, Luque US, Morrison D, Pérez SN, Perez-Llano J, Seguí FL, Vèrges AS. Telemedicine in the face of the COVID-19 pandemic. Atencion primaria. 2020 Jun;52(6):418.

17. O'Leary DE. Evolving Information Systems and Technology Research Issues for COVID-19 and Other Pandemics. Journal of Organizational Computing and Electronic Commerce. 2020 May 4:1-8.

18. Goldschmidt K. The COVID-19 pandemic: Technology use to support the wellbeing of children. Journal of Pediatric Nursing. 2020 Apr 16.

19. Nigerian Bar Association, https://conference.nigerianbar.org (accessed 3 August 2020).

20. Jiang P, Van Fan Y, Klemeš JJ. Impacts of COVID-19 on energy demand and consumption: Challenges, lessons and emerging opportunities. Applied Energy. 2021:116441.

21. Henriques, M. Will Covid-19 have a lasting impact on the environment? available at https://www.bbc.com/future/article/20200326-covid-19-the-impact-of-coronaviruson-the-environment.

22. Baldé CP, Forti V, Gray V, Kuehr R, Stegmann P. The global e-waste monitor 2017: Quantities, flows and resources. United Nations University, International Telecommunication Union, and International Solid Waste Association; 2017.

23. United Nations Environment Programme (UNEP) Press Release. 'UN Report: Time to Seize Opportunity, Tackle Challenge of E-Waste. (2019).

24. Basel Convention on the Control of Transboundary Movements of Hazardous Wastes and Their Disposal (Basel Convention), 1989.

25. Convention on the Ban of the Import into Africa and the Control of Transboundary Movement and Management of Hazardous Wastes Within Africa (Bamako Convention), 1991.

26. Wirth DA. 'Hazardous Substances and Activities,' in Bodansky D et al (eds), The Oxford Handbook of International Environmental Law. Oxford University Press, 2010.

27. Lawal S. Nigeria Has Become an E-Waste Dumpsite for Europe, US and Asia. TRT World, 15 February, 2019 available at https://www.trtworld.com/magazine/nigeriahas-become-an-e-waste-dumpsite-for-europe-us-and-asia-24197 (accessed 15 July 2020)

28. Carlarne CP. Climate change law and policy: EU and US approaches. Oxford University Press, USA; 2010.

29. Ogunseitan OA. The Basel Convention and e-waste: translation of scientific uncertainty to protective policy. The Lancet Global Health. 2013 Dec 1;1(6):e313-4.

30. Special Report, 'Down in the Dumps,' The Economist, 14 August, 2018, available at https://www.eeconomist.com/special-report/2018/08/14/down-in-the-dumps (accessed 15 July 2020).

31. Vidal J. 'Toxic E-Waste' Dumped in Poor Nations, Says United Nations,' The Guardian online, Saturday 14 December, 2013, available at https://www.theguatdian.com/globaldevelopment/2013/dec/14/toxic-ewaste-illegal-dumping-developing-countries (accessed 17 July 2020).

32. Carney L. 'Nigeria Fears E-Waste 'Toxic Legacy,' BBC World Services Dirty Business, Tuesday 19 Dec, 2006.

33. Fehm S. From iPod to e-Waste: Building a Successful Framework for Extended Producer Responsibility in the United States. Pub. Cont. LJ. 2011;41:173.

34. Grant K, Goldizen FC, Sly PD, Brune MN, Neira M, van den Berg M, Norman RE. Health consequences of exposure to e-waste: a systematic review. The lancet global health. 2013 Dec 1;1(6):e350-61. 
35. Wang K, Qian J, Liu L. Understanding environmental pollutions of informal e-waste clustering in global south via multi-scalar regulatory frameworks: a case study of Guiyu Town, China. Int. J. Environ. Res. Public Health. 2020:17(8);2802.

36. United States Environmental Protection Agency, 'Understanding Global Warming Potentials,' 14 February, 2017, available at https://www.epa.gov/climatechange/ghgemissions/gwps.html (accessed 15 July 2020).

37. Sieff K. 'The World is Drowning in Ever-Growing Mounds of Garbage,' The Washington Post, 21 November, 2017, available at https://www.washingtonpost.com/world/africa/the-world-is-drowning-in-evergrowing-mounds-of-garbage/2017/11/21/cf22e4bd-17a473c-89f8-

873d48f968cd_story.html (accessed 12 July 2020).

38. Arogundade S. 'A glance at Biggest Dumpsites in Nigeria,' BioEnergy Consult, 16 October, 2019, available at https://www.bioenergyconsult.com/biggest-dumpsites-innigeria/ (accessed 15 July 2020).

39. Amokaye OG. Environmental Law and Practice in Nigeria, $\left(2^{\text {nd }}\right.$ ed). MIJ Professional Publishers, Nigeria; 2014.

40. Chong E, Yosypiv IV. Developmental programming of hypertension and kidney disease. Int J Nephrol. 2012;760580. doi: 10.1155/2012/760580.

41. Thind PS, Sareen A, Singh DD, Singh S, John S. Compromising situation of India's bio-medical waste incineration units during pandemic outbreak of COVID-19: Associated environmental-health impacts and mitigation measures. Environmental Pollution. 2021 May 1;276:116621.

42. Oyedotun TD, Kasim OF, Famewo A, Oyedotun TD, Moonsammy S, Ally N, RennMoonsammy DM. Municipal waste Management in the era of COVID-19: Perceptions, Practices, and Potentials for Research in Developing Countries. Research in Globalization. 2020 Dec 1;2:100033.

43. McAllister L, Magee A, Hale B. Women, e-waste, and technological solutions to climate change. Health and Human Rights Journal. 2014 Jun 1;16(1):166-78.

44. United Nations Environmental Programme, available at https://www.unenvironment.org/explore-topics/environmental-rights-andgovernance/what-we-do/meeting-international-environmental_accessed 15 July 2020).

45. Case C-41/02 Commission v Netherlands (Dutch Vitamins) [2004] ECR I-11375, Cited in Damien Chalmers et al, European Union Laws: Cases and Materials $\left(2^{\text {nd }}\right.$ Ed) Cambridge University Press (2010), pp.898-899.

46. Case C-2/90 Commission v Belgium (Walloon Waste) [1992] ECR 1-4431.

47. Case C-203/96 Chemische Afvalstoppen Dusseldorp BV and Others v Minister van Volkhuisvesting, Ruimtelijke Ordening en Milieubeheer [1998] ECR I-4075.

48. Gamaralalage D, Premakumara J. 'Development of E-waste Management Policy at the Local Level: A Case Study of Cebu City, Philippines,' Institute for Global Environmental Strategies (2016) https://www.iges.or.jp/en/pub/development-e-wastemanagement-policy-local/en (accessed 15 July 2020).

49. Onojeghen T. 'Koko Community Can Never Recover From 1988 Toxic Waste Saga,' The Punch Newspaper, 3 March, 2018.

50. Cap Hi Laws of the Federation of Nigeria LFN, 2010.

51. https://www.nesrea.gov.ng/wpcontent/uploads/2020/02/Sanitation_and_Wastes_Control_Regulations\%202009.pdf (accessed 5 July 2020).

52. https://www.nesrea.gov.ng/wp-content/uploads/2020/02/Electrical_Electronics.pdf (accessed 5 July 2020). 
53. Nigerian Communications Commission, 'We will Collaborate with NESREA to achieve a cleaner Environment in Nigeria,' https://www.ncc.gov.ng/mediacentre/news-headlines/660-we-will-collaborate-with-nesrea-to-achieve-a-cleanerenvironment-in-nigeria-danbatta (accessed 5 August 2020).

54. UNEP, 'Nigeria turns the Tide on electronic waste' https://www.unenvironment.org/news-and-stories/press-release/nigeria-turns-tideelectronic-waste (accessed 5 July 2020).

55. Premium Times, 'NESREA raises concerns over dangers of e-waste' https://www.premiumtimesng.com/health/health-news/372924-nesrea-raises-concernover-danger-of-e-waste.html (accessed 7 July 2020).

56. Benebo NS. 'Status of e-waste Legislation in Nigeria' https://www.google.com/url?sa=t\&rct=j\&q=\&esrc=s\&source=web\&cd=\&cad=rja\&u act $=8 \&$ ved $=2$ ahUKEwiUmNv-

84LrAhXwxoUKHWhcDVwQFjACegQIBBAB\&url=http\%3A\%2F\%2Fwww.basel.i nt $\% 2$ FPortals\%2F4\%2Fdownload.aspx\%3Fd\%3DUNEP-CHW-PAFEW.1-PRESNesrea.English.pdf\&usg=AOvVaw3YlJXBdyG9OvKpFU1CgUVU (accessed 15 July 2020).

57. Oteng-Ababio MM, Amankwaa EF. The e-waste conundrum: Balancing evidence from the North and on-the-ground developing countries' realities for improved management. African Review of Economics and Finance. 2014 Aug 25;6(1):181-204.

58. Adanu SK, Gbedemah SF, Attah MK. Challenges of adopting sustainable technologies in e-waste management at Agbogbloshie, Ghana. Heliyon. 2020 Aug 1;6(8):e04548.

59. Otieno I, Omwenga E. E-waste management in Kenya: challenges and opportunities. Journal of Emerging Trends in Computing and Information Sciences. 2015 Dec;6(12):661-6.

60. Patil RA, Ramakrishna S. A comprehensive analysis of e-waste legislation worldwide. Environmental Science and Pollution Research. 2020 May;27(13):14412-31.

61. Sustainable Recycling Industries. 'International e-Waste Management Practice Country Factsheets from Twelve Jurisdictions' https://www.sustainable-recycling.org/wpcontent/uploads/2021/03/e-Waste_Management_Practice_Country-

Factsheets_Final.pdf (accessed 12 March 2021).

62. Supian NS, Shah GL, Yusof MB. Current waste generation of e-waste and challenges in developing countries: an overview. Malaysian Journal of Civil Engineering. 2015;27(1).

63. Chung SW, Murakami-Suzuki R. A comparative study of e-waste recycling systems in Japan, South Korea and Taiwan from the EPR perspective: implications for developing countries. Kojima. Chiba. 2008;21.

64. Vijarania M, Gupta S, Gambhir A. Challenges and strategies for E-waste management in developing countries. IJ Sci. Eng.. 2017;2:64-8.

65. Nnorom IC, Osibanjo O. Overview of prospects in adopting remanufacturing of endof-life electronic products in the developing countries. International Journal of Innovation, Management and Technology. 2010 Aug 1;1(3):328.

66. Liu Q, Li KQ, Zhao H, Li G, Fan FY. The global challenge of electronic waste management. Environmental Science and Pollution Research. 2009 May;16(3):248-9.

67. Sharma P, Fulekar MH, Pathak B. E-Waste-A challenge for tomorrow. Res. Jr. of Recent Sci. 2012;1(3):86-93.

68. Sullivan J. 'Trash or Treasure: Global Trade and the Accumulation of E-Waste in Lagos, Nigeria,' 61(1) Africa Today (2014): 89-112. 
69. Oluduro OF, Gasu GN. The Imperative of a Legislative Response to the Problem of EWaste in Africa, VII (1\&2) African Journal of Institutions and Development (2012): 120-131; European Commission, 'Environment,' 23 March, 2020. Available at https://ec.europa.eu/environment/waste/weee/index_en.htm (accessed 15 July 2020). 